\title{
Dating past geomorphic processes with tangential rows of traumatic resin ducts
}

\author{
Markus Stoffel* \\ Laboratory of Dendrogeomorphology (Dendrolab. ch), Department of Geosciences, University of Fribourg, Chemin du Musée 4, \\ 1700 Fribourg (FR), Switzerland
}

\begin{abstract}
Past activity of geomorphic processes can be reconstructed on tree-ring series using the presence of injuries, reaction wood or abrupt changes in the annual increment. The analysis of these features provides valuable data on years with process activity. In contrast, an intra-annual dating has so far normally only been possible through the analysis of injuries. In this technical note, it is shown that, in tree-ring studies realized with conifers, resin ducts may have the potential for providing information on the intra-seasonal timing of past geomorphic processes as well. However, because ducts may occur as a result of influences other than geomorphic, detailed field investigations and the identification of processes present at the study site imperatively need to precede dendrogeomorphological investigations.

Data obtained from 1298 cross-sections indicate that the presence of resin ducts in Picea abies (L.) Karst. and Larix decidua Mill. can be considered to be the result of geomorphic activity if they form tangentially oriented rows with a compact and continuous arrangement of traumatic ducts. The presence of resin ducts may also help to improve the quality of reconstructions in studies using Abies alba Mill. as vertical resin ducts occur exclusively at or next to injuries. In contrast, resin ducts apparently cannot be used for dendrogeomorphological analyses of Pinus ssp.
\end{abstract}

Keywords: Resin ducts; Geomorphic processes; Dendrogeomorphology; Conifers

\section{Introduction}

Reconstructions of past geomorphic processes and events are generally based upon the inspection and dating of visible injuries (e.g., LePage and Bégin, 1996; Baumann and Kaiser, 1999; Hohl et al., 2002; Stoffel and Perret, 2006; Stoffel and Bollschweiler, 2008), the presence of reaction wood (e.g., Clague and Souther, 1982; Denneler and Schweingruber, 1993; Fantucci and Sorriso-Valvo, 1999; Stefanini, 2004) or on abrupt

\footnotetext{
*Tel.: +412630090 15; fax: +41263009746.

E-mail address: markus.stoffel@unifr.ch.
}

changes in the yearly increment of trees following an event (e.g., LaMarche, 1968; Strunk, 1997; Bachrach et al., 2004; Stoffel et al., 2005a, 2006). Also, the age of trees colonizing geomorphic forms can be assessed to determine the minimum ages of surfaces or deposits (e.g., Alestalo, 1971; Motyka, 2003, Harrison et al., 2006; Pierson, 2007).

Whilst all of these approaches provide valuable data on periods or years with geomorphic activity, a highresolution, intra-annual dating has so far only normally been possible through the analysis of injuries. Reaction wood caused by tilting events, in contrast, has been shown to occur, at best, in the outer part of the growth 
ring of the year following tilting. In a similar way, "abrupt" changes in ring width (i.e. growth suppression or release) could not always be allocated within the growth ring either. For these reasons, several studies have begun to analyze tangential rows of traumatic resin ducts (TRD) over the last few years in order to improve the dating accuracy in dendrogeomorphological research (Lafortune et al., 1997; Stoffel et al., 2005b, c, 2006, 2008; Stoffel and Beniston, 2006), but these did not provide details on what TRD looked like and which criteria were used to consider this feature in the reconstructions.

In the present technical note, (i) examples are provided as to when and how TRD may be used for the dating of past geomorphic activity. In addition, the paper aims at (ii) documenting to what degree the inclusion of TRD may improve dating precision or the number of dated events, before (iii) limitations of the approach are highlighted.

\section{Which tree species produce resin and what causes formation of traumatic resin duct?}

Resin ducts are formed as a normal feature of development in tissues and organs, or their formation may be induced by external factors: Whilst pine trees produce copious amounts of resin terpenoids in the constitutive wood and developing secondary xylem (Phillips and Croteau, 1999), most other species limit the production of resin, under normal conditions, to the phloem in order to maintain an outer defense barrier (Martin et al., 2002). De novo formation of TRD in the developing secondary xylem is, by contrast, only observed after insect attack, fungal elicitation or any form of mechanical wounding (e.g., Fahn et al., 1979; Langenheim, 2003; McKay et al., 2003; Hudgins et al., 2004).

Mechanical wounding of the cambium and the formation of resin ducts may occur as the result of abrasion processes and wood-penetrating impacts caused by various geomorphic processes, including rockfall, rockslides, debris flows, flooding or snow avalanches. In addition, more superficial scars in juvenile trees may be the result of ungulate fraying and browsing. The presence of lateral tension in relation to the radial growth of the stem has also been reported as a trigger for resin-duct formation (Hug, 1979). Lastly, dendroecological studies have shown recently that extreme climatic conditions (droughts, water stress) can lead to the formation of resin ducts in certain conifer species as well (e.g., Wimmer and Grabner, 1997; Levanic, 1999; Rigling et al., 2002, 2003).

Jeffrey (1905) made a classification of conifers based on the anatomy of their secretory structures: In the stem of fir (Abies ssp.), cedar (Cedrus ssp.), hemlock (Tsuga ssp.), and golden larch (Pseudolarix ssp.), resin-producing cells form blisters, which are sac-like structures lined by epithelial cells. These cells are short-lived, and their walls become lignified during development (Nagy et al., 2000). Tube-like resin ducts represent a more complex structure and are found in the wood and bark of spruce (Picea ssp.), pine (Pinus ssp.), larch (Larix ssp.), and Douglas fir (Pseudotsuga ssp.). In these genera, resin is synthesized by thin-walled, long-lived secretory epithelial cells (Nagy et al., 2000).

But how much time does it take a tree to produce resin ducts after disturbance? Several experimental studies highlight that TRD are formed almost immediately after an event: Given any insect attack, fungal elicitation, or mechanical wounding occurred during the growth period of the tree, resin production starts only a few days after the event, and axial ducts emerge from the developing secondary xylem within less than 3 weeks after disturbance (see Ingemarsson and Bollmark, 1997; Ruel et al., 1998; Martin et al., 2002; McKay et al., 2003; Luchi et al., 2005).

\section{When should traumatic resin ducts be considered to be the result of geomorphic processes?}

It has been illustrated above that resin ducts may result from various disturbances. Consequently, detailed field studies, as well as the identification of processes present at the study site, imperatively need to precede dendrogeomorphological investigations. In addition, data from undisturbed reference trees must be sampled so as to separate years with widespread resin-duct formation caused by insect attacks or climatic events (i.e. droughts) from TRD induced by geomorphic processes. The appearance and nature of resin ducts then need to be analyzed in the area of wounding, abrasion or decapitation so as to define the characteristic features of "geomorphic resin-duct events". In this technical note, the identification of such features was based on 1298 cross-sections (949 scars) of different conifer species (i.e. Abies alba Mill., Larix decidua Mill., Picea abies (L.) Karst., Pinus cembra ssp. sibirica and Pinus sylvestris L.). The selected samples were taken from trees that have been scarred or abraded by past rockfall, debris flows or snow avalanches. An overview of the material analyzed is provided in Table 1. In a subsequent step, the characteristic features of tangential rows of TRD developed next to wounds were compared with those observed on 4336 increment cores of trees injured by rockfall, debris flow and snow-avalanche events (Table 2) so as to test the features and to identify "geomorphic resin-duct events" in these samples as well. As a rule, the first decade of juvenile growth rings has 
Table 1. Material used for the determination of characteristic features of "geomorphic resin-duct events"

\begin{tabular}{|c|c|c|c|c|c|}
\hline $\begin{array}{l}\text { Geomorphic } \\
\text { process }\end{array}$ & Study site & Species & Samples & Scars & Data source \\
\hline Rockfall & Altdorf & Abies, Picea & 193 & 86 & Stoffel $(2005,2006)$ \\
\hline Rockfall & Täschgufer & Larix & 270 & 180 & Stoffel et al. (2005b) \\
\hline Rockfall & Schwarzenberg & Picea & 100 & 68 & Perret (2005) \\
\hline Rockfall & Schwarzenberg & Picea & 33 & 301 & Perret et al. (2006) \\
\hline Debris flow & Laggina & Larix & 280 & 45 & Bollschweiler et al. (2008) \\
\hline Snow avalanche & Sitstafol & Larix & 324 & 212 & Stoffel et al. (2007) \\
\hline Snow avalanche & Gadmen & Picea & 98 & 57 & This study \\
\hline Total & & & 1298 & 949 & \\
\hline
\end{tabular}

Table 2. Material used for the identification of characteristic "resin-duct events" on increment cores (for details see text; $\mathrm{GD}=$ growth disturbances incl. compression wood, scars, TRD and abrupt growth changes)

\begin{tabular}{|c|c|c|c|c|c|}
\hline Geomorphic process & Study site & Species & Samples & GD & Data source \\
\hline Rockfall & Täschgufer & Larix & 564 & 761 & Stoffel et al. (2005c) \\
\hline Debris flow & Bruchji & Larix, Picea & 802 & 960 & Bollschweiler et al. (2007) \\
\hline Debris flow & Ritigraben & Larix, Picea, Pinus & 2450 & 2263 & Stoffel and Beniston (2006) \\
\hline Snow avalanche & Birchbach & Larix, Picea & 520 & 561 & Stoffel et al. (2006) \\
\hline Total & & & 4336 & 4545 & \\
\hline
\end{tabular}

not been included in the analysis, as tree rings in seedlings tend to produce more resin ducts per unit area in general (Larson, 1994), but only a few ducts around wounds located near the pith (Bannan, 1936).

Data obtained from the cross-sections indicate that the presence of resin ducts should only be considered to be the result of a geomorphic process if they form tangentially oriented rows with a compact and continuous arrangement of traumatic ducts. Characteristic examples of tangential rows of TRD are given in Fig. 1(a) and (b), with microsections from $L$. decidua and $P$. abies. It has also been observed that the formation of continuous TRD is restricted to strong geomorphic impacts with subsequent major damage caused to the tree (e.g., wood-penetrating impacts, abrasion); otherwise, $P$. abies and $L$. decidua did not necessarily form tangential rows but rather only a limited number of scattered ducts in the tree ring. As such a vague distribution of resin ducts may be caused by processes other than geomorphic (e.g., climate, insect attack, fungal elicitation), they should not be used for dendrogeomorphological purposes so as to exclude misinterpretation and faulty dating of past geomorphic events.

In $A$. alba, vertical resin ducts are absent from the secondary xylem, except at injuries where they occur in tangential series (Bannan, 1936). Given the process causing the scars identified in the field, the presence of resin ducts in $A$. alba can be declared to be undoubtedly the result of geomorphic activity. Fig. 1(c) provides a typical example of TRD in A. alba.
Further reliable indicators for the presence of cambium damage by past geomorphic activity are multiple series of TRD occurring in the immediate vicinity of the wound. Examples of multiple tangential series of TRD in the year of wounding and succeeding years are illustrated in Fig. 2. Franceschi et al. (2002) suggest that these multiple series of TRD are formed as a result of continuous production of signaling agents over several growing seasons, and that the TRD belong to the same initial event.

Based on our data, it seems to be impossible to identify "geomorphic resin-duct events" in $P$. cembra and $P$. sylvestris. These two subspecies produce abundant vertical resin ducts in their phloem and xylem, but, at the same time, do not produce characteristic TRD next to injuries as a reaction to mechanical wounding (Fig. 3). These observations are in agreement with Münch (1923) or Bannan (1936), who reported that ducts in Pinus ssp. are practically always scattered and that loose tangential series with widely separated ducts occur only very rarely.

\section{What is the "added value" of TRD analysis in dendrogeomorphological studies?}

Abrasion processes and wood-penetrating impacts not only cause injuries to trees, but also leave TRD next 

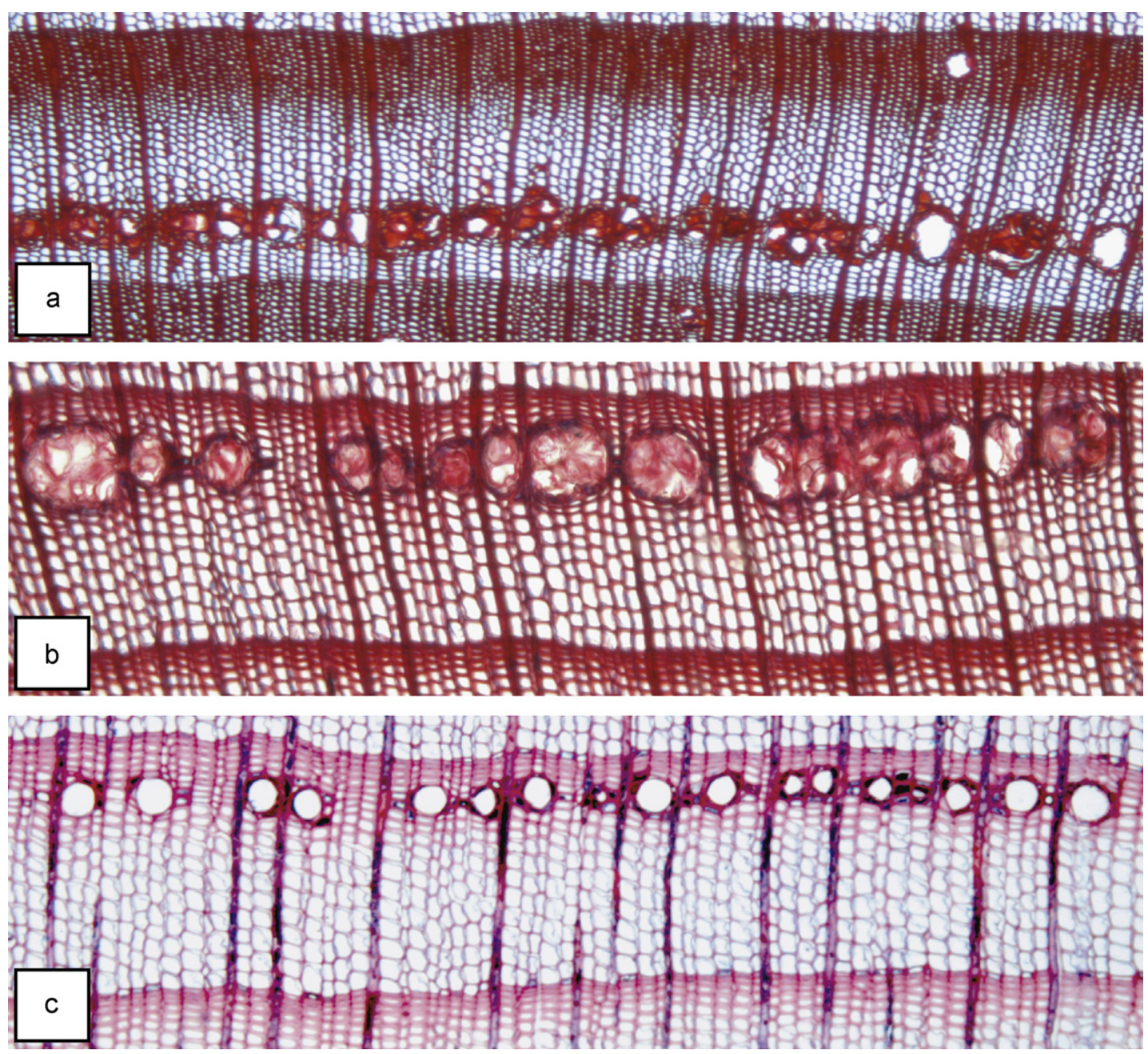

Fig. 1. Characteristic examples of tangential rows of traumatic resin ducts (TRD) bordering impact scars in (a) Larix decidua Mill., (b) Picea abies (L.) Karst. and (c) Abies alba Mill. (approximate magnification: $50 \times$ ).

to the wound. Based on Bollschweiler et al. (2008), TRD can, on average, be identified in almost one-fifth of the total circumference remaining vital after the impact, and thus allow identification of events even if the crosssections or increment cores are not taken directly at the location of the wound. This is especially helpful in the analysis of past events in $L$. decidua and $P$. abies where the thick bark and the sporadic peeling off of small bark pieces may totally conceal evidence of past events (Stoffel, 2005; Stoffel and Perret, 2006).

In addition, TRD develop in increasing numbers in the vertical and lateral extension of adult trees, even if the circumstances of the impact remain uniform (Thomson and Sifton, 1925; Bannan, 1936). This increase in the number of resin ducts apparently owes its origin to a greater sensitivity to wounding with age of species like $A$. alba, $L$. decidua and $P$. abies.

From our data, it also seems that TRD constitute the most commonly observed signature of a past growth anomaly on increment cores, and that some $44-86 \%$ of reconstructed growth disturbances would have remained undetected, had the presence of TRD not been taken into account (Table 3). The predominance of TRD is most obvious in the rockfall samples from 'Täschgufer', where century-old $L$. decidua trees were chosen for analysis. Data also shows that the large surfaces affected and the important volumes involved in debris flows and snow avalanches more commonly tilt trees and cause the subsequent formation of reaction wood than do individual rockfall fragments.

Fig. 4 illustrates that in the snow-avalanche samples gathered at 'Birchbach' and in the debris-flow trees selected at 'Bruchji', the loss of information would have been less important with 9\% each. Disregarding TRD would have had, in contrast, drastic consequences for the analysis of past rockfall activity at 'Täschgufer' where $77 \%$ of all events would have been missed if we had taken into account the analysis of wounds, callus tissue, reaction wood, growth release and growth suppression alone. 

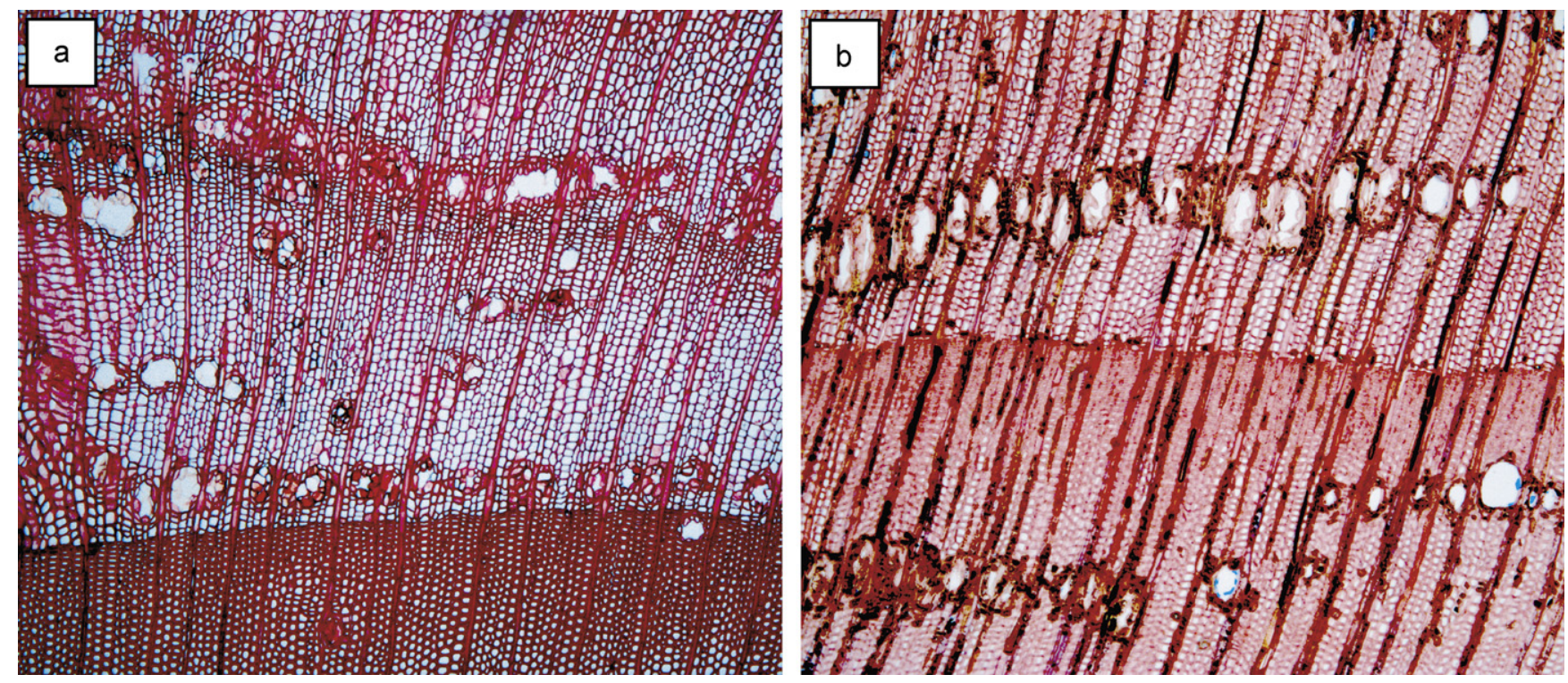

Fig. 2. After wounding, a tangential series is normally formed at the wound, but occasionally a number of later series may arise, either in the same or in succeeding rings. Multiple series of TRD in (a) Larix decidua Mill. and in (b) Abies alba Mill. (approximate magnification: $50 \times$ ).
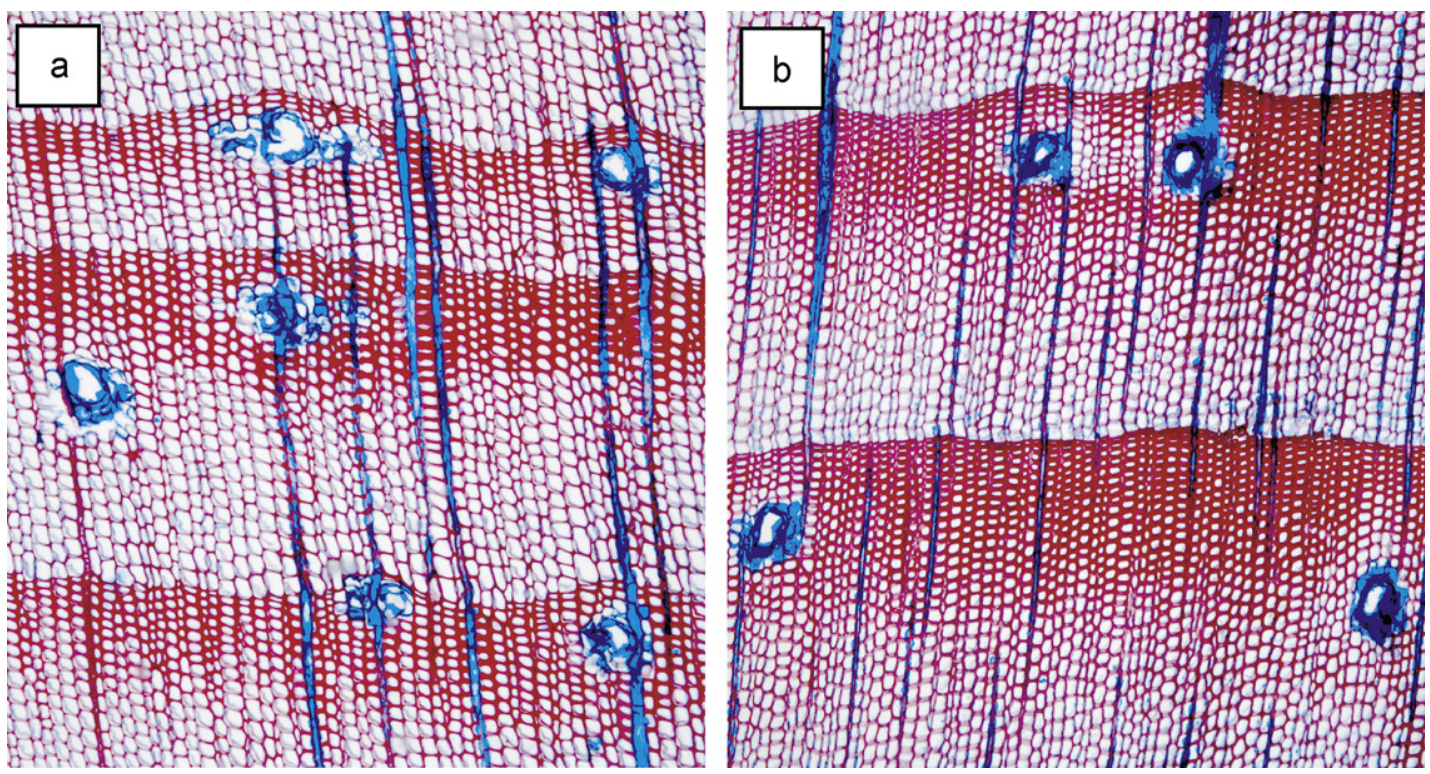

Fig. 3. (a) Pinus sylvestris L. and (b) Pinus cembra ssp. sibirica trees are not suitable for the dating of "geomorphic resin-duct events", as these species do not produce characteristic TRD as a reaction to wounding (approximate magnification: $50 \times$ ).

Table 3. Relative importance of different tree-ring signatures used to date past geomorphic events

\begin{tabular}{llccc}
\hline Signatures of past events (in \%) & $\begin{array}{l}\text { Rockfall } \\
\text { Täschgufer }\end{array}$ & $\begin{array}{l}\text { Debris flow } \\
\text { Ritigraben }\end{array}$ & $\begin{array}{l}\text { Debris flow } \\
\text { Bruchji }\end{array}$ & $\begin{array}{l}\text { Snow avalanche } \\
\text { Birchbach }\end{array}$ \\
\hline TRD & 86 & 44 & 59 & 61 \\
Wound/callus tissue & 2 & 6 & 4 & 7 \\
Reaction wood & 3 & 32 & 15 & 22 \\
Growth release & 3 & 9 & 10 & 4 \\
Growth suppression & 6 & 9 & 12 & 6 \\
\hline
\end{tabular}




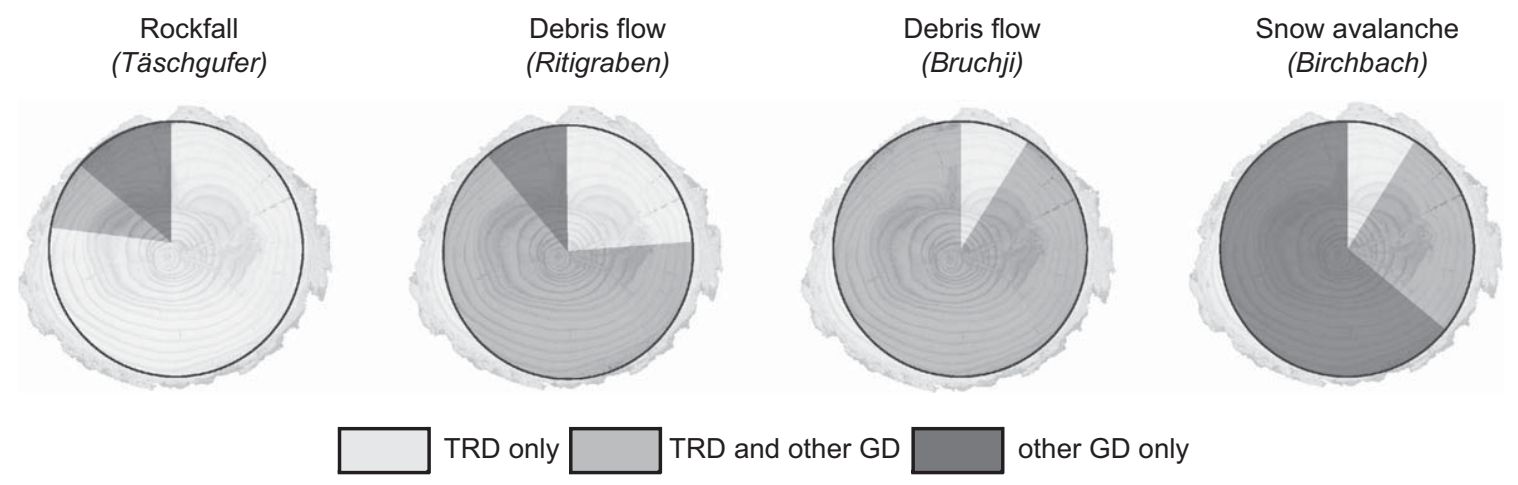

Fig. 4. Relative number of events dated via the presence of (a) TRD only, (b) TRD and other growth disturbances (GD; i.e. wounds, callus tissue, reaction wood, growth release, growth suppression) and (c) only growth disturbances (GD) other than TRD.

The importance of TRD analysis in geomorphic studies can be further emphasized by the results from the debris-flow study at 'Ritigraben': Here, a first detailed analysis focusing on all growth disturbances, except for TRD, yielded sufficient evidence for 53 events between AD 1605 and today (Stoffel et al., 2005a). A reassessment of all growth disturbances, including TRD, allowed a densification of the frequency to 123 events as well as an extension of the reconstruction back to AD 1570 (Stoffel and Beniston, 2006; Stoffel et al., 2007, in press). Fig. 4 indicates that part of this increase was due to the identification of events that were only present on the tree-ring series via TRD (24\%). On the other hand, events that have previously not been considered because of their weak confirmation in a few tree-ring series could now be dated with more confidence, as a large number of samples were showing TRD.

\section{Where are the limitations of the TRD approach and what questions remain?}

The consideration of tangential rows of TRD in dendrogeomorphological studies may help to improve and enlarge the reconstruction of past activity. Among the geomorphic processes analyzed in tree-ring research, debris flows, rockfall, rockslides, snow avalanche and flooding (carrying solid charge) appear to be particularly well suited for analysis. In addition, dating of windstorm events should be possible, and there is probably even a potential for earthquake studies. In contrast, the approach seems to be, at a first glance, of little help for landslide analyses, as this process preferably tilts trees and damages roots rather than causing injuries to stems.

Similarly, not all resin-producing species are equally well suited for the analysis of past geomorphic activity using TRD. L. decidua and P. abies have been shown to represent the two species with the largest potential, even more so as their thick bark regularly overgrows ('hides') evidence of past events. The approach can be used with $A$. alba to a limited degree as well, but because resin ducts are normally located very close to the injury, and as the later ones remain visible on the stem surface most of the time (Stoffel and Perret, 2006), the "added value" of TRD analysis can be considered to be of minimal value here. In contrast, resin ducts should not be considered for the analysis of past events when working with $P$. sylvestris or $P$. cembra, as they do not occur in tangential rows and are thus obviously produced by various kinds of external disturbances.

It is also known that if the injury has been severe, TRD may extend laterally and as far as several decimeters vertically from the wound with no, or only a small amount of, radial movement in the rings of Larix and Picea (Mayr, 1884; Bannan, 1936). As the thick bark and the sporadic peeling off of small bark pieces may totally hide evidence of past events in $L$. decidua and P. abies, it is often much easier to identify signatures of past events by the presence of TRD, rather than by scars on increment cores. But we still do not really know the maximal distance from the injury at which TRD can be identified in the tree-ring series and to what degree this distance would depend on the intensity of the impact. One of the few experimental studies existing suggests that decapitation of young Pinus pinea trees would result in resin ducts being formed in (at least) the first $10 \mathrm{~cm}$ below the wound (Lev-Yadun, 2002).

Finally, TRD may occur not only in the tree ring of the year of disturbance, but also in those rings formed in the years following an event. Although the tangential spread of TRD is usually most significant when it first occurs after an impact (Bollschweiler et al., 2008), important tangential extensions of TRD in the years following an event have been observed on a very limited number of samples as well. Consequently, analyses may run the risk of faulty dating if reconstructions are exclusively based on the presence of one single TRD occurring on one individual increment core. 


\section{Conclusions}

This technical note has focused upon the potential of tangential rows of TRD in the analysis of past geomorphic processes in forested environments. Given that detailed analysis of resin ducts developed as a result of wounding or tree decapitation are performed and characteristic features for "geomorphic resin-duct events" assessed, TRD form a valuable tool for the identification of past rockfall, snow avalanche or debrisflow events in the tree-ring series of $L$. decidua, $P$. abies or $A$. alba. As conifers immediately produce resin ducts after mechanical wounding, the assessment of TRD within the tree ring may also improve dating precision and reduce the amount of misinterpreted dating caused by the potentially retarded onset of reaction wood or growth changes.

\section{Acknowledgements}

I express my gratitude to Michelle Bollschweiler for fruitful discussions and for her comments on an earlier version of the note, and to Bill Harmer for proofreading.

\section{References}

Alestalo, J., 1971. Dendrochronological interpretation of geomorphic processes. Fennia 105, 1-139.

Bachrach, T., Jakobsen, K., Kinney, J., Nishimura, P., Reyes, A., Laroque, C.P., Smith, D.J., 2004. Dendrogeomorphological assessment of movement at Hilda rock glacier, Banff National Park, Canadian rocky mountains. Geografiska Annaler 86A, 1-9.

Bannan, M.W., 1936. Vertical resin ducts in the secondary wood of the Abietineae. New Phytologist 35, 11-46.

Baumann, F., Kaiser, K.F., 1999. The Multetta debris fan, eastern Swiss Alps: a 500-year debris flow chronology. Arctic, Antarctic and Alpine Research 31, 128-134.

Bollschweiler, M., Stoffel, M., Ehmisch, M., Monbaron, M., 2007. Reconstructing spatio-temporal patterns of debrisflow activity using dendrogeomorphological methods. Geomorphology 87 (4), 337-351.

Bollschweiler, M., Stoffel, M., Schneuwly, D.M., Bourqui, K., 2008. Where do traumatic resin ducts occur in Larix decidua that have been impacted by debris flows? Tree Physiology 28, 255-263.

Clague, J.J., Souther, J.G., 1982. The dusty creek landslide on Mount Caylay, British Columbia. Canadian Journal of Earth Sciences 19, 524-539.

Denneler, B., Schweingruber, F.H., 1993. Slow mass movement. A dendrogeomorphological study in Gams, Swiss Rhine Valley. Dendrochronologia 11, 55-67.

Fahn, A., Werker, E., Ben-Zur, P., 1979. Seasonal effects of wounding and the growth substances on development of traumatic resin ducts in Cedrus libani. New Phytologist 82, $537-544$

Fantucci, R., Sorriso-Valvo, M., 1999. Dendrogeomorphological analysis of a slope near Lago, Calabria (Italy). Geomorphology 30, 165-174.

Franceschi, V.R., Krekling, T., Christiansen, E., 2002. Application of methyl jasmonate on Picea abies (Pinaceae) stems induces defense-related responses in phloem and xylem. American Journal of Botany 89, 578-586.

Harrison, S., Glasser, N., Winchester, V., Haresign, E., Warren, C., Jansson, K., 2006. A glacial lake outburst flood associated with recent mountain glacier retreat, Patagonian Andes. Holocene 16, 611-620.

Hohl, R., Schweingruber, F.H., Schiesser, H.H., 2002. Reconstruction of severe hailstorm occurrence with tree rings: a case study in central Switzerland. Tree Ring Research 58, 11-22.

Hudgins, J.W., Christiansen, E., Franceschi, V.R., 2004. Induction of anatomically based defense responses in stems of diverse conifers by methyl jasmonate: a phylogenetic perspective. Tree Physiology 24, 251-264.

Hug, U.E., 1979. Das Harzkanalsystem im juvenilen stammholz von Larix decidua mill. Schweizerische Zeitschrift für Forstwesen 61, 1-127.

Ingemarsson, B.S., Bollmark, M., 1997. Ethylene production and 1-amino-cyclopropane-1-carboxylic acid turnover in Picea abies hypocotyls after wounding. Journal of Plant Physiology 151, 711-715.

Jeffrey, E.C., 1905. The comparative anatomy and phylogeny of the Coniferales, Part 2. The Abietineae. Bulletin of the Boston Society of Natural History 6, 1-37.

Lafortune, M., Filion, L., Hétu, B., 1997. Dynamique d'un front forestier sur un talus d'éboulis actif en climat tempéré froid (Gaspésie, Québec). Géographie Physique et Quaternaire 51, $1-15$.

LaMarche, V.C., 1968. An 800-year history of stream erosion as indicated by botanical evidence. US Geological Survey Professional Paper 550D, 83-86.

Langenheim, J.H., 2003. Plant Resins: Chemistry, Evolution, Ecology, and Ethnobotany. Timber Press, Portland, OR, p. 586.

Larson, P.R., 1994. The Vascular Cambium: Development and Structure. Springer, Berlin, Heidelberg, New York, p. 725 .

LePage, H., Bégin, Y., 1996. Tree-ring dating of extreme water level events at Lake Bienville, Subarctic Québec, Canada. Arctic and Alpine Research 28, 77-84.

Levanic, T., 1999. Vertical resin ducts in wood of black pine (Pinus nigra Arnold) as a possible dendroecological variable. Phyton (Horn) 39, 123-127.

Lev-Yadun, S., 2002. The distance to which wound effects influence the structure of secondary xylem of decapitated Pinus pinea. Journal of Plant Growth Regulation 21, 191-196.

Luchi, N., Ma, R., Capretti, P., Bonello, P., 2005. Systemic induction of traumatic resin ducts and resin flow in Austrian pine by wounding and inoculation with Sphaeropsis sapinea and Diplodia scrobiculata. Planta 221, 75-84.

Martin, D., Tholl, D., Gershenzon, J., Bohlmann, J., 2002. Methyl jasmonate induces traumatic resin ducts, terpenoids resin 
biosynthesis, and terpenoids accumulation in developing xylem of Norway spruce stems. Plant Physiology 129, 1003-1018.

Mayr, H., 1884. Entstehung und Vertheilung der Secretionsorgane der Fichte und Lärche. Botanische Zeitschrift 20.

McKay, S.A.B., Hunter, W.L., Godard, K.A., Wang, S.X., Martin, D.M., Bohlmann, J., Plant, A.L., 2003. Insect attack and wounding induce traumatic resin duct development and gene expression of (-)-Pinene synthase in Sitka spruce. Plant Physiology 133, 368-378.

Motyka, R.J., 2003. Little ice age subsidence and post little ice age uplift at Juneau, Alaska, inferred from dendrochronology and geomorphology. Quaternary Research 59, 300-309.

Münch, E., 1923. Zur Anatomie der Harzgänge von Pinus silvestris. Botanisches Archiv 4, 195-200.

Nagy, N.E., Franceschi, V.R., Solheim, H., Krekling, T., Christiansen, E., 2000. Wound-induced traumatic resin duct development in stems of Norway spruce (Pinaceae): anatomy and cytochemical traits. American Journal of Botany 87, 301-313.

Perret, S., 2005. Rockfall-forest interaction: inventory, analysis and simulation of rockfall activity in mountain forests. Ph.D. Thesis, University of Berne.

Perret, S., Stoffel, M., Kienholz, H., 2006. Spatial and temporal rockfall activity in a subalpine forest stand in the Swiss Prealps - a dendrogeomorphological case study. Geomorphology 74, 219-231.

Phillips, M.A., Croteau, R., 1999. Resin-based defenses in conifers. Trends in Plant Science 4, 184-190.

Pierson, T.C., 2007. Dating young geomorphic surfaces using age of colonizing Douglas fir in southwestern Washington and northwestern Oregon, USA. Earth Surface Processes and Landforms 32, 811-831.

Rigling, A., Bräker, O.U., Schneiter, G., Schweingruber, F.H., 2002. Intra-annual tree-ring parameters indicating differences in drought stress of Pinus sylvestris forests within the EricoPinion in the Valais (Switzerland). Plant Ecology 163, 105-121.

Rigling, A., Brülhardt, H., Bräker, O.U., Forster, T., Schweingruber, F.H., 2003. Irrigation effect on tree growth and vertical resin duct production of Pinus sylvestris L. on dry sites in the central Alps, Switzerland. Forest Ecology and Management 175, 285-296.

Ruel, J.J., Ayres, M.P., Lorio, P.L., 1998. Loblolly pine responds to mechanical wounding with increased resin flow. Canadian Journal of Forest Research 28, 596-602.

Stefanini, M.C., 2004. Spatio-temporal analysis of a complex landslide in the northern Apennines (Italy) by means of dendrochronology. Geomorphology 63, 191-202.

Stoffel, M., 2005. Assessing the vertical distribution and visibility of scars in trees. Schweizerische Zeitschrift für Forstwesen 156, 195-199.
Stoffel, M., 2006. A review of studies dealing with tree rings and rockfall activity: the role of dendrogeomorphology in natural hazard research. Natural Hazards 39, 51-70.

Stoffel, M., Beniston, M., 2006. On the incidence of debris flows from the early little ice age to a future greenhouse climate: a case study from the Swiss Alps. Geophysical Research Letters 33, L16404.

Stoffel, M., Bollschweiler, M., 2008. Tree-ring analysis in natural hazards research - an overview. Natural Hazards and Earth System Sciences 8, 1-15.

Stoffel, M., Perret, S., 2006. Reconstructing past rockfall activity with tree rings: some methodological considerations. Dendrochronologia 24, 1-15.

Stoffel, M., Lièvre, I., Conus, D., Grichting, M.A., Raetzo, H., Gärtner, H.W., Monbaron, M., 2005a. 400 years of debris flow activity and triggering weather conditions: Ritigraben VS, Switzerland. Arctic, Antarctic and Alpine Research 37, 387-395.

Stoffel, M., Lièvre, I., Monbaron, M., Perret, S., 2005b. Seasonal timing of rockfall activity on a forested slope at Täschgufer (Valais, Swiss Alps) - a dendrochronological approach. Zeitschrift für Geomorphologie 49, 89-106.

Stoffel, M., Schneuwly, D., Bollschweiler, M., Lièvre, I., Delaloye, R., Myint, M., Monbaron, M., 2005c. Analyzing rockfall activity (1600-2002) in a protection forest - a case study using dendrogeomorphology. Geomorphology 68, 224-241.

Stoffel, M., Bollschweiler, M., Hassler, G.R., 2006. Differentiating events on a cone influenced by debris-flow and snow avalanche activity - a dendrogeomorphological approach. Earth Surface Processes and Landforms 31, 1424-1437.

Stoffel, M., Bollschweiler, M., Hassler, G.R., Monbaron, M., 2007. Reconstitution de la dynamique spatio-temporelle des avalanches dans le Nanztal et le Lötschental - une approche dendrogéomorphologique. Bulletin de la Murithienne, in press.

Stoffel, M., Conus, D., Grichting, M.A., Lièvre, I., Maître, G., 2008. Unraveling the patterns of late Holocene debris-flow activity on a cone in the central Swiss Alps: chronology, environment and implications for the future. Global and Planetary Change 60, 222-234.

Strunk, H., 1997. Dating of geomorphological processes using dendrogeomorphological methods. Catena 31, 137-151.

Thomson, R.B., Sifton, H.B., 1925. Resin canals in the Canadian spruce (Picea canadensis (Mill.) B.S.P.). Royal Society Philosophical Transactions B 214, 63-111.

Wimmer, R., Grabner, M., 1997. Effects of climate on vertical resin duct density and radial growth of Norway spruce (Picea abies (L.) Karst.). Trees 11, 271-276. 